\title{
Phyto-Morphological and Growth Variations in Oil Palm Seedlings under Influence of Microbial Fertilizers and Agrochemicals
}

\author{
Veeramachaneni Suneetha ${ }^{1 *}$ and K. Ramachandrudu ${ }^{2}$ \\ ${ }^{1}$ Department of Biotechnology, Jawaharlal Nehru Technological University, \\ Hyderabad-500 085, India \\ ${ }^{2}$ ICAR-Indian Institute of Oil Palm Research, Pedavegi-534 450, West Godavari District, \\ Andhra Pradesh, India \\ *Corresponding author
}

Keywords

Oil palm, Microbial fertilizers,

Seedling, Growth, Dry matter.

Article Info

Accepted:

17 June 2018

Available Online:

10 July 2018

\section{A B S T R A C T}

The nursery experiment was conducted to observe influence of microbial fertilizers on growth of oil palm seedlings for two consecutive years. Azotobacter chroococcum, Azospirillum brasilense, Bacillus megaterium, Frateuria aurantia and Glomus aggregatum were the microbial fertilizers used individually, combindly and integrated with chemical fertilizers. All the treatments were found markedly superior to the control with respect to morphological and growth characters of oil palm seedlings. Among the treatments, most convincing and highly significant results for seedling height $(78.87 \mathrm{~cm})$, number of leaves (12.33), leaflets/leaf $(52.08)$, leaf area $\left(1391 \mathrm{~cm}^{2}\right)$, stem girth $(16.62 \mathrm{~cm})$, number of primary roots $(17.45)$, root volume $(186.58 \mathrm{cc})$, net photosynthetic rate $\left(13.85 \mu \mathrm{mol} \mathrm{m}^{-2} \mathrm{~s}^{-}\right.$ $\left.{ }^{1}\right)$, total chlorophyll $\left(1.63 \mathrm{mg} \mathrm{g}^{-1}\right)$ and dry matter $(200.53 \mathrm{~g})$ recorded under integrated application of microbial fertilizers $+25 \%$ recommended dose of fertilizers. Among individual microbial fertilizers, Glomus aggregatum showed outstanding performance which was better than $100 \%$ RDF and it was equally effective when compared with combined use of microbial fertilizers in most of the growth parameters. Results of the study indicated that minimal dose of chemical fertilizers is required for exploiting the best possible benefits from microbial fertilizers. Based on excellent performance, integrated use of microbial fertilizers with $25 \%$ of recommended dose of chemical fertilizers is recommended for commercial application in oil palm nurseries in India.

\section{Introduction}

Oil palm (Elaeis guineensis Jacq.), the highest vegetable oil yielding crop (4-6t/ha) in the world, is commercially cultivated to an extent of 3.05 lakh hectares in India. It is a perennial crop with economic life span of 25-30 years.
The growth and yield of oil palm in farmers' gardens mainly depend on the quality of seedlings produced in the nursery. Nutrition at the nursery stage plays significant role in establishment of healthy and productive oil palm gardens. Normally, heavy dose of chemical fertilizers is applied in oil palm 
nursery to meet the nutrient demand. Of late, a great attention is focussed on the possibility of using self sustainable and environment friendly agents like microbial fertilizers for boosting the growth and vigour of oil palm seedlings during nursery stage.

Studies showed that Azospirillum inoculation stimulated top growth by $30 \%$, root growth by $60 \%$, and net photosynthetic rate as compared with the control (Amir et al., 2001). The information available on influence of microbial fertilizers in oil palm is very limited and mostly confined to partial duration of the nursery. Moreover, there is no research work on this aspect in oil palm in India. Therefore, the present experiment was conducted to generate sustainable technology to replace or cut down the amount of chemical fertilizers used in oil palm nursery.

\section{Materials and Methods}

The present study was carried out for two consecutive years at ICAR-Indian Institute of Oil Palm Research (IIOPR), Pedavegi, West Godavari District, Andhra Pradesh, India. Experimental site is located at $16^{\circ} 43^{\prime} \mathrm{N}$ and $81^{\circ} 09^{\prime} \mathrm{E}$ with a mean sea level of $13.41 \mathrm{~m}$. The climate of the site is hot and humid and average annual minimum and maximum temperature ranges from $22.6^{\circ} \mathrm{C}$ to $34.6^{\circ} \mathrm{C}$, average annual relative humidity is $66.5 \%$ and rainfall is $1074 \mathrm{~mm}$. The completely randomized design (CRD) with eleven treatments and five replications was employed for the study.

Oil palm nursery was raised for 12 months in double stage system i.e., primary stage for 4 months and secondary stage for 8 months. Black coloured polythene bags of $23 \mathrm{~cm}$ x 15 $\mathrm{cm}$ were used for raising seedlings in primary stage under 50 per cent UV stabilized HDPE shade net whereas polythene bags of $45 \mathrm{~cm} \mathrm{x}$ $38 \mathrm{~cm}$ were used for raising seedlings in secondary nursery under open conditions Tank silt and farm yard manure (FYM) mixed in $2: 1(\mathrm{v} / \mathrm{v})$ ratio was used as a potting mixture for raising oil palm seedlings. Uniform, healthy and 65 days old oil palm seed sprouts of Tenera hybrid combination (1140 Dura $\mathrm{x}$ 1988 Pisifera) were used as a planting material for the study.

Lignite based Azotobacter chroococcum $\left(1 \times 10^{8}\right.$ cfu g-1), Azospirillum brasilense $\left(1 \times 10^{8}\right.$ cfu g-1), Bacillus megaterium $\left(1 \times 10^{8}\right.$ cfu g-1), Frateuria aurantia $\left(1 \times 10^{8}\right.$ cfu g-1) and soil based Glomus aggregatum (800 infectious propagules g-1) were procured from Agricultural Research Station, ANGRAU, Amaravathi, Guntur District, Andhra Pradesh. In individual treatments, each microbial inoculum was applied to potting mixture thrice at 4 month interval i.e., at the time of planting of seed sprouts, shifting of primary seedlings to secondary stage bags and finally 8 months after planting of sprouts and the quantity of biofertilizers per bag used was $10 \mathrm{~g}, 25 \mathrm{~g}$ and $5 \mathrm{~g}$, respectively. In the combined and integrated treatments, Bacillus megaterium, Frateuria aurantia and Glomus aggregatum with above mentioned doses while Azotobacter chroococcum (5, 12.5 and 2.5g) and Azospirillum brasilense (5, 12.5 and 2.5g) with $50 \%$ of above mentioned doses per bag were mixed together and applied to the potting mixture. Initial dose of microbial fertilizers was applied in a small pit made in the potting medium for planting of oil palm seed sprout. Second dose of microbial fertilizers was applied in the pit and around the rhizosphere of the primary seedling at the time of shifting to secondary stage poly bag and the final dose was given in one inch deep circular trench made around the seedling. Recommended chemical fertilizers for oil palm nursery viz., di-ammonium phosphate (DAP) and NPK (17:17:17) complex were used in the study. 
Morphological characters of oil palm seedlings such as seedling height, number of leaves, stem girth, petiole depth, petiole width, number of leaflets/leaf, number of primary roots, total root volume and biomass of seedlings were recorded at 4 stages at 3 month interval i.e., Stage-1 after 3 months, Stage- 2 after 6 months, Stage-3 after 9 months and Stage-4 after 12 months of the nursery by following destructive method given by Corley et al (1971). Leaf area was estimated by measuring the length and width of all the leaves of seedlings at stage- 1 and length and width of the third leaf from the top at stage- 2 . Leaf area of the third leaf from the top at stage- 3 and stage- 4 was calculated by non destructive method (Corley et al., 1971). Net photosynthetic rate $(\mathrm{Pn})$ was recorded at stage2 and stage- 4 by using a Portable Photosynthesis System. Similarly, chlorophyll content in leaves was quantified at stage- 2 and stage-4 of oil palm nursery by using method of Hiscox and Israelstam (1979). GLM procedure of the statistical software SAS version 9.3 was used for statistical analysis of experimental data.

\section{Results and Discussion}

An integrated application of microbial fertilizers $+25 \%$ RDF (T7) outperformed among others and it was highly significant as compared to the control for seedling height, leaves and leaflets (Table 1). Improved seedling height $(78.87 \mathrm{~cm})$ and leaf production (12.33) under T7-biofertilizers $+25 \%$ RDF may be due to enhanced nutrient uptake, photosynthetic rate, better partitioning of photosynthates towards leaf production and production of plant growth hormones. The results of the present study are in concomitant with those of Aseri and Rao (2005) and Noor Ai'shah et al. (2009) in ber and oil palm seedlings, respectively. Among individual treatments, it is worth to note that T5-Glomus aggregatum $(72.07 \mathrm{~cm})$ was found at par with
T6-combined use of microbial fertilizers $(73.60 \mathrm{~cm})$ and both were found significantly superior to $\mathrm{T} 10-100 \% \mathrm{RDF}(68.67 \mathrm{~cm})$. This is in agreement with the finding of Noor Ai'shah et al., (2009) in oil palm seedlings. Higher level of nutrient uptake and increased photosynthetic rate and transpiration rate might be responsible for enhanced seedling height under Glomus aggregatum.

Treatment T7-integrated application of microbial fertilizers $+25 \%$ RDF (1391.69 $\mathrm{cm} 2$ ) followed by T8-microbial fertilizers + $50 \%$ RDF $(1317.35 \mathrm{~cm} 2)$ were notably superior to other treatments in leaf area (Table 1). This can be attributed to production of more number of leaves, leaflets/leaf and higher photosynthetic rate. Baset Mia et al (2006) in banana plantlets obtained similar results. Significant enhancement in leaf area as a result of integrated use of microbial fertilizers + chemical fertilizers may be due to production of phytohormones by microbial fertilizers and improved availability of nutrients. Treatments T1-Azotobacter chroococcum $\left(1094.98 \mathrm{~cm}^{2}\right)$ and T5-Glomus aggregatum $\left(1135.60 \mathrm{~cm}^{2}\right)$ were significantly higher than the control $\left(873.36 \mathrm{~cm}^{2}\right)$ and both were found on par with T6-combined use of microbial fertilizers $\left(1183.06 \mathrm{~cm}^{2}\right)$ and T10$100 \%$ RDF $\left(1127.97 \quad \mathrm{~cm}^{2}\right) . \quad$ Similar observation of enhanced leaf area was reported in pomegranate cuttings (Aseri et al., 2008) and Marsdenia volubilis (Sandhya et al., 2013) seedlings upon inoculation with nitrogen fixing bacteria and AMF.

All the treatments except T10-100\% RDF were significantly superior to the control with respect to petiole width and depth (Table 2). Among the treatments, maximum petiole width $(1.80 \mathrm{~cm})$ and petiole depth $(1.49 \mathrm{~cm})$ was observed with T5-Glomus aggregatum. Considerable improvement in petiole width and depth in inoculated seedlings can be ascribed to better assimilation of nutrients and 
photosynthetic rate. Notable improvement in stem girth (Table 2) over the control was noticed with integrated application of microbial fertilizers + RDF particularly at $25 \%(\mathrm{~T} 7-16.62 \mathrm{~cm}))$ and $50 \%(\mathrm{~T} 8-16.03 \mathrm{~cm})$. Present findings are in accordance with the findings of Seema Paroha et al (2009) in teak seedlings. Of all the individual treatments, best results for stem girth were recorded with T5-Glomus aggregatum $(15.00 \mathrm{~cm})$ which was found at par with T6-combined application of microbial fertilizers $(15.65 \mathrm{~cm})$. Sevanan et al., (2009) reported similar results in Melia azedarach nursery. Enhanced stem girth in inoculated seedlings can be ascribed to release of growth promoting substances and enhanced nutrient availability in the root zone, better uptake of nutrients and storage of photosynthates.

Of all the treatments, the highest number of (Table 2) primary roots/seedling (17.45) and maximum root volume (Table 3) were observed under T7-microbial fertilizers $+25 \%$ RDF (186.58 cc) which was apparently superior to other treatments except T8microbial fertilizers $+50 \%$ RDF $(164.27 \mathrm{cc})$. The results are in accordance with the findings of Noor Ai'shah et al (2009) in oil palm seedlings. Improved root volume in T7microbial fertilizers $+25 \%$ RDF can be correlated with better root growth i.e., more number of primary roots and root volume. Among individual treatments, T5-Glomus aggregatum showed significant results for primary roots (14.79) and root volume (138.17 cc) when compared with the control (12.49, $107.48 \mathrm{cc}$ ) and it was found on par with T10$100 \%$ RDF $(13.96,149.50 \mathrm{cc})$.

Better root volume under inoculated treatments can be ascribed to the plant growth promoting substances especially IAA which might have proliferated root hair production. Similar conclusions were made by Sivakumar (2001) in mango root stocks.
Treatment $\mathrm{T}_{7}$-microbial fertilizers $+25 \% \mathrm{RDF}$ excelled among others by recording the highest net photosynthetic rate $(13.85 \mu \mathrm{mol}$ $\left.\mathrm{m}^{-2} \mathrm{~s}^{-1}\right)$ and maximum total chlorophyll content $\left(1.63 \mathrm{mg} \mathrm{g}^{-1}\right)$ in leaves while the minimum values $\left(9.66 \mu \mathrm{mol} \mathrm{m} \mathrm{m}^{-2} \mathrm{~s}^{-1}, 1.16 \mathrm{mg}\right.$ $\mathrm{g}^{-1}$ ) were estimated under the control (Table 3). Similar results were noticed in banana plantlets grown under hydroponic condition (Baset Mia et al., 2006). Higher values of net

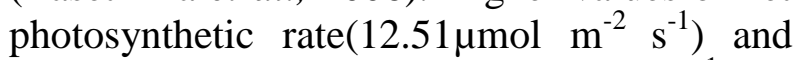
total chlorophyll content $\left(1.29 \mathrm{mg} \mathrm{g}^{-1}\right)$ in leaves were manifested in $\mathrm{T}_{5}$-Glomus aggregatum which was significantly superior to the control and it was found at par with $\mathrm{T}_{6^{-}}$ combined use of microbial fertilizers (12.49 $\mu \mathrm{mol} \mathrm{m} \mathrm{m}^{-2}, 1.41 \mathrm{mg} \mathrm{g}^{-1}$ ) and $\mathrm{T}_{10}-100 \% \mathrm{RDF}$ $\left(11.85 \mu \mathrm{mol} \mathrm{m} \mathrm{m}^{-1}, 1.16 \mathrm{mg} \mathrm{g}^{-1}\right)$. Improved chlorophyll content in inoculated seedlings is an indicative of enhanced $\mathrm{Mg}, \mathrm{Fe}$ and $\mathrm{Cu}$ uptake which are essential for biosynthesis of chlorophyll in plants. The higher $\mathrm{N}$ in inoculated seedlings also might have contributed to the formation of chlorophyll which consequently could have increased the photosynthetic activity. In addition, AMF may function as a metabolic sink causing basipetal mobilization of photosynthates to roots thus providing a stimulus for greater photosynthetic activity (Bevege et al., 1975). The present study confirms the reports of Aseri and Rao (2005) in ber seedlings and Baset Mia et al (2006) in banana plantlets.

Among the treatments, the maximum dry matter was recorded under Treatment T7microbial fertilizers + 25\% RDF (200.53 g). Significant enhancement in seedling dry matter under T7-microbial fertilizers $+25 \%$ RDF might be due to vigorous growth of seedlings with more number of leaves, leaflets and root density which is certainly due to greater absorption of nutrients, higher photosynthetic rate and metabolic activities and accumulation of nutrients in plant tissues. 
Table.1 Effect of microbial fertilizers and chemical fertilizers on morphological characters of oil palm seedlings during the nursery stage

\begin{tabular}{|c|c|c|c|c|c|c|c|c|c|c|c|c|}
\hline \multirow[t]{2}{*}{ Treatment } & \multicolumn{3}{|c|}{ Seedling height (cm) } & \multicolumn{3}{|c|}{ Leaves/seedling } & \multicolumn{3}{|c|}{ Leaflets/leaf } & \multicolumn{3}{|c|}{ Leaf area $\left(\mathrm{cm}^{2}\right)$} \\
\hline & $1^{\mathrm{st}} \mathrm{yr}$ & $2^{\text {nd }} \mathrm{yr}$ & $\begin{array}{l}\text { Pooled } \\
\text { mean }\end{array}$ & $1^{\mathrm{st}} \mathrm{yr}$ & $2^{\text {nd }} y r$ & $\begin{array}{l}\text { Pooled } \\
\text { mean }\end{array}$ & $1^{\mathrm{st}} \mathrm{yr}$ & $2^{\text {nd }} \mathrm{yr}$ & $\begin{array}{c}\text { Pooled } \\
\text { mean }\end{array}$ & $1^{\mathrm{st}} \mathrm{yr}$ & $2^{\text {nd }} \mathrm{yr}$ & $\begin{array}{c}\text { Pooled } \\
\text { mean }\end{array}$ \\
\hline $\mathbf{T}_{1}$ & 74.30 & 66.07 & 70.20 & 11.92 & 11.50 & 11.71 & 43.50 & 45.33 & 44.42 & 1210.24 & 979.74 & 1094.98 \\
\hline $\mathbf{T}_{2}$ & 72.97 & 64.78 & 68.88 & 11.50 & 11.25 & 11.38 & 42.50 & 44.67 & 43.58 & 1070.52 & 987.32 & 1028.92 \\
\hline $\mathbf{T}_{3}$ & 75.40 & 63.79 & 69.61 & 11.50 & 11.25 & 11.38 & 45.17 & 46.00 & 45.58 & 1058.08 & 947.90 & 1002.99 \\
\hline $\mathbf{T}_{4}$ & 72.58 & 60.54 & 66.55 & 11.67 & 10.17 & 10.92 & 44.17 & 46.33 & 45.25 & 1075.17 & 899.45 & 987.31 \\
\hline $\mathbf{T}_{5}$ & 77.99 & 66.15 & 72.07 & 11.75 & 11.34 & 11.54 & 49.17 & 48.00 & 48.59 & 1230.20 & 1041.00 & 1135.60 \\
\hline $\mathbf{T}_{6}$ & 78.47 & 68.80 & 73.60 & 12.09 & 11.42 & 11.76 & 52.84 & 42.33 & 47.58 & 1218.08 & 1148.05 & 1183.06 \\
\hline $\mathbf{T}_{7}$ & 82.95 & 74.80 & 78.87 & 12.42 & 12.25 & 12.33 & 55.50 & 48.67 & 52.08 & 1512.64 & 1270.73 & 1391.69 \\
\hline $\mathbf{T}_{8}$ & 79.63 & 70.74 & 75.20 & 12.25 & 11.25 & 11.75 & 52.50 & 48.67 & 50.58 & 1483.66 & 1151.05 & 1317.35 \\
\hline $\mathbf{T}_{9}$ & 77.48 & 65.04 & 71.26 & 12.00 & 10.58 & 11.29 & 50.50 & 42.33 & 46.42 & 1307.39 & 1032.51 & 1169.95 \\
\hline $\mathbf{T}_{10}$ & 75.61 & 60.53 & 68.07 & 11.92 & 10.25 & 11.08 & 48.84 & 42.00 & 45.42 & 1303.57 & 952.38 & 1127.97 \\
\hline$T_{11}$ & 68.20 & 55.39 & 61.67 & 11.09 & 9.50 & 10.29 & 41.17 & 37.67 & 39.42 & 955.35 & 791.37 & 873.36 \\
\hline LSD-5\% & & & 3.17 & & & 0.59 & & & 3.65 & & & 164.75 \\
\hline SEM & & & 5.57 & & & 1.04 & & & 4.52 & & & 289.75 \\
\hline
\end{tabular}

$\mathrm{T}_{1}$-Azotobacter chroococcum, $\mathrm{T}_{2}$-Azospirillum brasilense, $\mathrm{T}_{3}$-Bacillus megaterium, $\mathrm{T}_{4}$-Frateuria aurantia, $\mathrm{T}_{5}$-Glomus aggregatum, $\mathrm{T}_{6}$-Mixture of microbial fertilizers, $\mathrm{T}_{7}$-Biofertilizers $+25 \% \mathrm{RDF}, \mathrm{T}_{8}$-Microbial fertilizers $+50 \% \mathrm{RDF}, \mathrm{T}_{9}$-Microbial fertilizers $+75 \% \mathrm{RDF}, \mathrm{T}_{10}-100 \%$ RDF and $\mathrm{T}_{11}$-Control. 
Table.2 Effect of microbial fertilizers and chemical fertilizers on petiole width, depth, stem girth and root production of oil palm seedlings during the nursery stage

\begin{tabular}{|c|c|c|c|c|c|c|c|c|c|c|c|c|}
\hline \multirow[t]{2}{*}{ Treatment } & \multicolumn{3}{|c|}{ Petiole width (cm) } & \multicolumn{3}{|c|}{ Petiole depth $(\mathrm{cm})$} & \multicolumn{3}{|c|}{ Stem girth $(\mathrm{cm})$} & \multicolumn{3}{|c|}{ Primary roots } \\
\hline & $1^{\text {st }} \mathrm{yr}$ & $\begin{array}{l}2^{\text {nd }} \\
\mathrm{yr}\end{array}$ & $\begin{array}{c}\text { Pooled } \\
\text { mean }\end{array}$ & $1^{\mathrm{st}} \mathrm{yr}$ & $2^{\text {nd }} \mathrm{yr}$ & $\begin{array}{c}\text { Pooled } \\
\text { mean }\end{array}$ & $1^{\mathrm{st}} \mathrm{yr}$ & $2^{\text {nd }} \mathrm{yr}$ & $\begin{array}{c}\text { Pooled } \\
\text { mean }\end{array}$ & $1^{\mathrm{st}} \mathrm{yr}$ & $2^{\text {nd }} y r$ & $\begin{array}{c}\text { Pooled } \\
\text { mean }\end{array}$ \\
\hline $\mathbf{T}_{1}$ & 1.72 & 1.78 & 1.75 & 1.41 & 1.33 & 1.37 & 15.84 & 12.89 & 14.36 & 16.32 & 13.17 & 14.74 \\
\hline $\mathbf{T}_{2}$ & 1.75 & 1.78 & 1.77 & 1.48 & 1.38 & 1.43 & 14.79 & 12.73 & 13.76 & 15.98 & 12.75 & 14.37 \\
\hline $\mathbf{T}_{\mathbf{3}}$ & 1.79 & 1.77 & 1.78 & 1.41 & 1.39 & 1.40 & 15.51 & 13.03 & 14.27 & 15.84 & 13.42 & 14.63 \\
\hline $\mathbf{T}_{4}$ & 1.50 & 1.84 & 1.67 & 1.34 & 1.34 & 1.34 & 14.77 & 12.44 & 13.60 & 15.09 & 12.92 & 14.00 \\
\hline $\mathbf{T}_{5}$ & 1.77 & 1.84 & 1.80 & 1.47 & 1.51 & 1.49 & 16.17 & 13.84 & 15.00 & 15.75 & 13.83 & 14.79 \\
\hline $\mathbf{T}_{6}$ & 1.65 & 1.69 & 1.67 & 1.45 & 1.36 & 1.40 & 16.51 & 14.80 & 15.65 & 17.66 & 15.23 & 16.44 \\
\hline $\mathbf{T}_{7}$ & 1.79 & 1.72 & 1.75 & 1.45 & 1.49 & 1.47 & 17.61 & 15.62 & 16.62 & 17.39 & 17.50 & 17.45 \\
\hline $\mathbf{T}_{8}$ & 1.58 & 1.58 & 1.58 & 1.34 & 1.37 & 1.35 & 16.46 & 15.61 & 16.03 & 16.92 & 16.17 & 16.54 \\
\hline $\mathbf{T}_{9}$ & 1.60 & 1.53 & 1.57 & 1.43 & 1.20 & 1.31 & 16.45 & 14.51 & 15.48 & 15.84 & 13.50 & 14.67 \\
\hline$T_{10}$ & 1.50 & 1.38 & 1.44 & 1.35 & 1.17 & 1.26 & 15.83 & 13.65 & 14.74 & 15.25 & 12.92 & 13.96 \\
\hline$T_{11}$ & 1.47 & 1.33 & 1.40 & 1.23 & 1.10 & 1.16 & 13.94 & 11.03 & 12.49 & 13.73 & 11.25 & 12.49 \\
\hline LSD-5\% & & & 0.14 & & & 0.09 & & & 1.02 & & & 1.37 \\
\hline SEM & & & 0.17 & & & 0.12 & & & 1.79 & & & 2.41 \\
\hline
\end{tabular}

$\mathrm{T}_{1}$-Azotobacter chroococcum, $\mathrm{T}_{2}$-Azospirillum brasilense, $\mathrm{T}_{3}$-Bacillus megaterium, $\mathrm{T}_{4}$-Frateuria aurantia, $\mathrm{T}_{5}$-Glomus aggregatum, $\mathrm{T}_{6}$-Mixture of microbial fertilizers, $\mathrm{T}_{7}$-Biofertilizers $+25 \% \mathrm{RDF}, \mathrm{T}_{8}$-Microbial fertilizers $+50 \% \mathrm{RDF}, \mathrm{T}_{9}$-Microbial fertilizers $+75 \% \mathrm{RDF}, \mathrm{T}_{10}-100 \%$ RDF and $\mathrm{T}_{11}$-Control. 
Table.3 Effect of microbial fertilizers and chemical fertilizers on growth parameters of oil palm seedlings during the nursery stage

\begin{tabular}{|c|c|c|c|c|c|c|c|c|c|c|c|c|}
\hline Treatment & \multicolumn{3}{|c|}{ Root volume (cc) } & \multicolumn{3}{|c|}{$\begin{array}{c}\text { Net photosynthetic rate } \\
\left(\mu \mathrm{mol} \mathrm{m}-{ }^{2} \mathbf{s}^{-1}\right)\end{array}$} & \multicolumn{3}{|c|}{ Total chlorophyll $\left(\mathrm{mg} \mathrm{g}^{-1}\right)$} & \multicolumn{3}{|c|}{ Dry matter (g) } \\
\hline $\mathbf{T}_{2}$ & 137.75 & 90.73 & 114.24 & 11.77 & 12.18 & 11.97 & 1.05 & 1.19 & 1.12 & 147.72 & 120.08 & 133.9 \\
\hline $\mathbf{T}_{3}$ & 166.67 & 105.96 & 136.31 & 11.18 & 11.67 & 11.42 & 1.05 & 1.22 & 1.13 & 156.38 & 126.04 & 141.21 \\
\hline $\mathbf{T}_{6}$ & 177.58 & 132.99 & 155.27 & 12.01 & 12.97 & 12.49 & 1.38 & 1.45 & 1.41 & 170.82 & 156.58 & 163.70 \\
\hline $\mathbf{T}_{7}$ & 214.00 & 159.17 & 186.58 & 13.37 & 14.35 & 13.85 & 1.63 & 1.64 & 1.63 & 232.52 & 168.54 & 200.53 \\
\hline $\mathbf{T}_{8}$ & 182.17 & 146.38 & 164.27 & 12.96 & 13.53 & 13.24 & 1.57 & 1.37 & 1.47 & 202.37 & 149.86 & 179.37 \\
\hline $\mathbf{T}_{9}$ & 175.84 & 137.88 & 156.85 & 12.34 & 11.42 & 11.88 & 1.36 & 1.25 & 1.31 & 201.07 & 143.36 & 172.21 \\
\hline $\mathbf{T}_{10}$ & 187.92 & 111.08 & 149.50 & 11.72 & 11.99 & 11.85 & 1.18 & 1.16 & 1.16 & 188.98 & 136.75 & 162.86 \\
\hline
\end{tabular}

$\mathrm{T}_{1}$-Azotobacter chroococcum, $\mathrm{T}_{2}$-Azospirillum brasilense, $\mathrm{T}_{3}$-Bacillus megaterium, $\mathrm{T}_{4}$-Frateuria aurantia, $\mathrm{T}_{5}$-Glomus aggregatum, $\mathrm{T}_{6}$-Mixture of microbial fertilizers, $\mathrm{T}_{7}$-Microbial fertilizers $+25 \% \mathrm{RDF}, \mathrm{T}_{8}$-Microbial fertilizers $+50 \% \mathrm{RDF}, \mathrm{T}_{9}$-Microbial fertilizers $+75 \% \mathrm{RDF}, \mathrm{T}_{10}-100 \% \mathrm{RDF}$ and $\mathrm{T}_{11}$-Control. 
Findings of the present study are confirmed with reports of Aseri and Rao (2005) in ber seedlings and Noor Aishah et al (2009) in oil palm seedlings. Among individual microbial fertilizers, T1-Azotobacter chroococcum, T5Glomus aggregatum and T3-Bacillus megaterium performed well and they were found on par with T6-combined use of microbial fertilizers and T10-100\% RDF with respect to dry matter production. Observations are in line with findings in oil palm plantlets (Amir et al., 2001).

Over all, results with regard to growth parameters clearly indicated that growth of oil palm seedlings under integrated use of microbial fertilizers + chemical fertilizers expressed maximum values for most of the growth characters when compared to other treatments. These results are in confirmation with the report of Mamta et al (2017) in papaya seedlings. Although, nutrients present in soil, the mobility of these nutrients into vegetative tissues is a big concern. Hence, the mobility of nutrients might be achieved by microbial fertilizers especially AMF rather than application of chemical fertilizers. Results of the present study clearly revealed that there was a decreasing trend in effect on seedling height, leaf production, leaf area, root production, stem girth and biomass production under integration of microbial fertilizers and chemical fertilizers as the chemical fertilizer dose was increased from 25 to $75 \%$ RDF.

Results of the current study reflected that T5Glomus aggregatum was found on par with T10-100\% RDF and T6-combined use of microbial fertilizers for growth parameters. Similarly, Umme Aminun Naher et al (2013) reported the remarkable improvement in growth of AMF inoculated oil palm seedlings as compared with inorganic fertilizers.

Therefore, it can be concluded from the foregoing results and discussion that outstanding performance for key characters like seedling height, number of leaves, leaf area, stem girth, number of primary roots, photosynthetic rate, total chlorophyll and dry matter was noticed under integrated application of microbial and chemical fertilizers $\left(T_{7}\right)$ rather than individual or combined use of different types of microbial fertilizers and $100 \%$ RDF. Hence, microbial fertilizers along with mild dose $(25 \% \mathrm{RDF})$ of chemical fertilizers can be exploited commercially for sustainable raising of oil palm nursery without affecting seedling growth and vigour.

\section{References}

Amir, H. G., Shamsuddin, Z. H and Halmi, M. S. 2001. Effects of Azospirillum inoculation on $\mathrm{N}_{2}$ fixation and growth of oil palm plantlets at nursery stage. J. Oil palm, 13(1): 42-49.

Aseri, G. K. and Rao, A.V. 2005. Interaction of bio-inoculants and chemical fertilizers on biomass production, rhizosphere activity and nutrient uptake of ber. Indian J. Forestry, 28: 58-64.

Aseri, G. K., Neelam Jain., Jitendra Panwar, Rao, A. V. and Meghwal. P.R. 2008. Biofertilizers improve plant growth, fruit yield, nutrition, metabolism and rhizosphere enzyme activities of pomegranate in Thar Desert. Sci. Hort., 117(: 130-135.

Baset Mia, M. A., Shamsuddin, Z.H., Wahab, Z. and Marziah, M. 2006. The effect of rhizobacterial inoculation on growth and nutrient accumulation of tissue cultured banana plantlets under low N-fertilizer regime. African J. Biotechnol., 8(21): 5855-5866.

Bevege, D. I., Bowen, G. D. and Skinner, M.F. 1975. Comparative carbohydrate physiology of ecto and 
endomycorrhizas. In: F.E. Sanders, B. Mosse and P.B. Tinker (Eds.), Endomycorrhizas, Academic Press, New York. Pp: 149-175.

Corley, R. H. V., Hardon, J. J. and Tan, G.Y. 1971. Estimation of growth parameters and application in breeding. Euphytica, 20: 307-315.

Hiscox, J. D. and Israelstam, G. F. 1979. A method for the extraction of chlorophyll from leaf tissues without maceration. Canadian J. Bot., 57: 1332-1334.

Mamta, K., Dash, D., Gupta, S. B. and Sonali, D. 2017. Effect of integrated nutrient management on growth and nutrient uptake in papaya at nursery level. $J$. Pharma. Phytoche., 6(5): 522-527.

Noor Ai'shah, O., Amir, H. G., Chan Lai Keng and Othman, A. R. 2009. Influence of various combinations of diazotrophs and chemical $\mathrm{N}$ fertilizer on plant growth and $\mathrm{N}_{2}$ fixation capacity of oil palm seedlings (Elaesis guineensis Jacq.). Thai J. Agri. Sci., 42(3): 139-149.

Sandhya, A., Vijaya, T., Sridevi, A. and Narasimha, G. 2013. Influence of vesicular arbuscular mycorrhiza (VAM) and phosphate solubilizing bacteria (PSB) on growth and biochemical constituents of Marsdenia volubilis. African J. Biotechnol., 12(38): 5648-5654.

Seema Paroha, Chandra, K. K. and Rakhi Yadav. 2009. Integrated effect of biofertilizers fertilizers (AM, Azotobacter and PSB) on growth and nutrient acquisition by Tectona grandis. J. Trop. Forestry, 25(1/2): 54-61.

Sevanan, R. K., Mathan C. N., Pandanilly C. P., Lakew Wondimu and Thangavel, S. 2009. Interaction between Glomus geosporum, Azotobacter chroococcum and Bacillus coagulans and their influence on growth and nutrition of Melia azedarach L. Turkish J. Biol., 33: 109-114.

Sivakumar, U. 2001. Effect of bacterial inoculants on mango rootstocks. Madras Agri. J., 88(7/9): 486-487.

Umme Aminun Naher, Radziah Othman and Qurban Ali Panhwar. 2013. Beneficial effects of mycorrhizal association for crop production in the Tropics - A Review. Int. J. Agri. Biol., 15: 10211028.

\section{How to cite this article:}

Veeramachaneni Suneetha and Ramachandrudu, K. 2018. Phyto-Morphological and Growth Variations in Oil Palm Seedlings under Influence of Microbial Fertilizers and Agrochemicals Int.J.Curr.Microbiol.App.Sci. 7(07): 2356-2364. doi: https://doi.org/10.20546/ijcmas.2018.707.274 